Geology

April 2015, Volume 43, Issue 4, Pages 331-334

Archimer

http://dx.doi.org/10.1130/G36170.1

http://archimer.ifremer.fr/doc/00254/36558/

(c) 2015 Geological Society of America. For permission to copy, contact

editing@geosociety.org.

\title{
Holocene turbidites record earthquake supercycles at a slow-rate plate boundary
}

Ratzov Gueorgui ${ }^{1,2}$, Cattaneo Antonio ${ }^{2}$, Babonneau Nathalie ${ }^{1}$, Déverchère Jacques ${ }^{1}$, Yelles Karim ${ }^{3}$, Bracene Rabah ${ }^{4}$, Courboulex Françoise ${ }^{5}$

${ }^{1}$ Université de Brest, CNRS UMR 6538, Domaines Océaniques, IUEM, 29280 Plouzané, France

${ }^{2}$ IFREMER, Géosciences Marines-EDROME, 29280 Plouzané, France

${ }^{3}$ Centre de Recherche en Astronomie Astrophysique et Géophysique, 16006 Algiers, Algeria

${ }^{4}$ SONATRACH Exploration, 35000 Boumerdès, Algeria

${ }^{5}$ Université de Nice/Sophia-Antipolis, CNRS, IRD, Observatoire de la Côte d'Azur, Géoazur UMR 7329,

250 rue Albert Einstein, 06560 Valbonne, France

\begin{abstract}
:
Ongoing evidence for earthquake clustering calls for records of numerous earthquake cycles to improve seismic hazard assessment, especially where recurrence times overstep historical records. We show that most turbidites emplaced at the Africa-Eurasia plate boundary off west Algeria over the past $\sim 8$ k.y. correlate across sites fed by independent sedimentary sources, requiring a regional trigger. Correlation with paleoseismic data inland and ground motion predictions support that $M \sim 7$ earthquakes have triggered the turbidites. The bimodal distribution of paleo-events supports the concepts of earthquake supercycles and rupture synchronization between nearby faults: 13 paleo-earthquakes underpin clusters of 3-6 events with recurrence intervals of $\sim 300-600 \mathrm{yr}$, separated by periods of quiescence of $\sim 1.6$ k.y. without major events on other faults over the study area. This implies broad phases of strain loading alternating with phases of strain release. Our results suggest that fault slip rates are time dependent and call for revising conventional seismic hazard models.
\end{abstract}




\section{Introduction}

Earthquake time series reveal that rupture occurrence depends on the history of the causative fault, but also of adjacent ones (Stein, 1999; Scholz, 2010). Two main limitations, however, exist in outcrop study of faults: the scarce access to faults and the short time span of earthquake time series. Chronostratigraphy of earthquake-triggered turbidites provides insightful paleo-earthquake records in subduction zones (Goldfinger et al., 2003) and helps in overcoming these limitations.

Turbidite paleoseismology relies on the fact that significant seafloor shaking during large earthquakes promotes multiple and widespread turbidity currents, depositing greater sediment volumes (Goldfinger et al., 2003, and references therein) than those triggered by climatic events (Einsele et al., 1996). A widespread synchronous trigger is a key assumption for reconstructing paleo-earthquake records. Synchroneity is established by counting, dating, and correlating deposits in independent channels (Goldfinger et al., 2003), basins (Gràcia et al., 2010), or sedimentary systems (Pouderoux et al., 2014).

Turbidite stratigraphy is a powerful tool to characterize the complex and multiscale seismic behavior of megathrusts and to evidence supercycles and superquakes (Goldfinger et al., 2013). However, the behavior of slow-rate plate boundaries has received little attention 
despite high seismic risks and patchy knowledge of full seismic cycles. We aim to reconstruct thousand-year-long time series of paleo-earthquakes that triggered large turbidity flows in a low-seismicity-rate setting, and highlight the cycling of earthquakes at a slow-convergence plate boundary.

\section{REGIONAL SETTING}

The Algerian margin is located at the diffuse boundary of the African plate converging at 3-6 mm $\mathrm{yr}^{-1}$ toward Eurasia (Stich et al., 2006). The A.D. $1954 \mathrm{Ms} 6.7$ Orléansville earthquake and the $2003 \mathrm{Mw} 6.8$ Boumerdes earthquake triggered widespread turbidity flows documented by submarine cable breaks (Heezen and Ewing, 1955; Cattaneo et al., 2012), supporting a turbidite paleoseismology approach. The area of the Orléansville and El Asnam earthquakes (Fig. 1) is an $\sim 150$-km-long margin segment where strain is located inland along northeast-southwest strike-slip faults and landward-verging thrusts and folds (Beldjoudi et al., 2011). The main active tectonic feature is the El Asnam fault system (EAFS) forming a complex set of deep ramps connecting laterally, followed upward by fault-propagation folds (Avouac et al., 1992). The 1954 Ms 6.7 Orléansville earthquake likely occurred along the deepest ramp without breaking the surface. In contrast, the 1980 Ms 7.3 El Asnam earthquake ruptured an 30-km-long frontal scarp (Meghraoui et al., 1988). The El Asnam earthquake did not trigger widespread turbidity currents, because no submarine cable broke offshore except a single cable $\sim 200 \mathrm{~km}$ eastward (El Robrini et al., 1985). From available surface faulting (Beldjoudi et al., 2011) and historical seismicity (Boughacha et al., 2004), whether faults other than the EAFS can produce $M>6.5$ earthquakes in this part of Algeria is unclear. Offshore El Asnam, the eastern continental slope is $3^{\circ}-4^{\circ}$ steep, dominated by the Kramis fan, fed by the Kramis and Khadra canyons (Fig. 1). The canyons are obliquely oriented (N170 and N090) and build an asymmetric 800-m-high levee (Babonneau et al., 2012). Westward and eastward, the slope is steeper (up to $\sim 16^{\circ}$ ) and shows numerous slump scars and gullies. No large active faults are observed offshore.

\section{METHODS}

\section{Scientific Rationale}

To infer the seismic trigger of turbidites, we test their synchroneity in three cores collected in two independent sedimentary systems (Fig. 1; Fig. DR1 in the GSA Data Repository). Core site KMDJ07 (2630 $\mathrm{m}$ below sea level, mbsl) isfed by turbidity flows coming from the Kramisturbidite system, whereas core KMDJ08 (2631 mbsl) samples the margin toe and collects onlyturbidity current deposits originated from theoverhanging slope. To avoid any local or climatically triggered turbidites (flood, hyperpycnal flow) which usually depict short runouts (Einsele et al., 1996), we collected core PSMKS19 (2626 mbsl) in the distal part of the Kramis fan (Fig. 1). As it is close to an A.D. 1954 cable break, it stands on the path of the earthquake-triggered turbidity currents. We then compare our record with the paleoseismic one on the ElAsnam fault scarp (Meghraoui et al., 1988).

Combined effects of lower sea level before ca. $8 \mathrm{ka}$ and wetter conditions in the Maghreb from the Bølling-Allerød stage (14.7-12.7 kyrB.P.) to ca. $8 \mathrm{kyr}$ B.P. (Barcena et al., 2001) favored the connection between river mouths and canyons, and the formation of hyperpycnal flows able to reach the coring sites. We thus limited our investigation to the past $\sim 8 \mathrm{k} . \mathrm{y}$. when the sea level was high and climate was drier and more stable, a period less favorable to the climatic triggering of large turbidity flows.

\section{Sediment Analyses and Dating}

We measure gamma density, porosity, and magnetic susceptibility at each centimeter on the cores. We split the cores for description, photography, X-ray imagery, magnetic 
susceptibility, and laser granulometry. Finally, we measure composition of major elements by X-ray fluorescence (Fig. 2; Figs. DR2 and DR3). Dating turbidites requires calculating the hemipelagic accumulation rate between successive ${ }^{14} \mathrm{C}$ ages dated on planktonic foraminifers (Fig. DR4) by subtracting all turbidites. We calibrate the radiocarbon dates, build age-depth models, and thus calculate the age of each turbidite (OxCal software; Figs. DR5-DR7). We choose an interpolation parameter allowing heterogeneous sediment deposition to account for possible erosion at the base of each turbidite that we cannot quantify.

\section{RESULTS AND INTERPRETATIONS}

The three cores KMDJ07, KMDJ08, and PSMKS19 show alternating light to dark olive beige, poorly sorted bioclastic silty clay, interpreted as background hemipelagic deposits, and dark olive gray to olive beds with a sharp, locally erosive silty base and a fining-upward grain size trend. These latter beds are interpreted as instantaneous turbiditic deposits (Fig. 2; Figs. DR1-DR3). The top of turbidites is determined by the analysis of several proxies. In northern Algeria, the watersheds are mainly calcareous, resulting into relatively low contrasts in carbonate content between turbidites tails and hemipelagites based on $\mathrm{Ca} / \mathrm{Fe}$ ratios (biogenic versus detrital fluxes) (Fig. 2B). This limits the use of variation in magnetic susceptibility, density, or geochemical composition, which are often used for accurate identification of turbidites (Goldfinger et al., 2003; Gràcia et al., 2010). Moreover, sediment sorting (Fig. 2C) reveals normally graded turbidites with a coarse base (up to $1000 \mu \mu$ ) fining upwards to silts and clays. The grain size distribution supports well-sorted deposits. Contrastingly, most hemipelagites are unsorted and show a plateau for grain size between $\sim 30$ and >300 $\mu \mu$ associated with biogenic particles (Fig. 2C). This criterion appears more reliable for discriminating turbidites from hemipelagites where the compositional contrast is low (Ratzov et al., 2010). Where discrimination remains uncertain (e.g., sediment mixing by bioturbation), we consider the interval as an uncertainty included in the age model (Fig. 2; Figs. DR2 and DR3).

Turbidites may be stacked without intervening hemipelagites in proximal cores KMDJ07 and KMDJ08. Such stacks may reflect: (1) simultaneous slope failures during an earthquake, (2) large aftershocks or earthquakes occurring closely in space and time, (3) pulses and flow discontinuities in the turbidity current (Van Daele et al., 2013), or (4) seafloor erosion of hemipelagites by the coarse fraction of the subsequent turbidite (Goldfinger et al., 2003). Because we hardly discriminate among these scenarios, we consider a single trigger where stacks contain no hemipelagites, and multiple triggers where the presence of hemipelagites is unclear.

We define an event (E) as a turbidite or a stack of turbidites that either corresponds to a historical earthquake or is synchronous in at least two cores. We identify 13 events based on turbidite correlation with overlapping age error bars across two or three cores (Figs. 2 and 3). Although the error bars of events may overlap, the stratigraphy of deposits allows establishing the number of events. Seven events are retrieved in all cores (E3, E5, E9, E10, E11, E12, and E13) and five correlate across two cores (E2 and E4 collected in the same system, E6, E7, and E8). Only two turbidites are single ones: T1 in core PSMKS19 (E1) and T10 in core KMDJ07 (Fig. 2A).

Ground-motion prediction equations applied to our case study show that $M>6.5$ earthquakes are required to produce a peak ground acceleration sufficient to promote slope failures (Fig. 4; Fig. DR8). Our study should therefore trace the cycling of $M>6.5$ earthquakes occurring approximately within the area mapped in Figure 1.

\section{DISCUSSION AND CONCLUSION From Turbidites to Paleo-Earthquakes}


The greater number of turbidites in more proximal cores (Fig. DR1) suggests that turbidites in our cores are not linked to climatic events (floods, hyperpycnal flows) that usually result in short runouts. Instead, the clear synchroneity of at least seven groups of turbidites supports a regional trigger that we interpret as coseismic. Although visible in a single core, turbidite T1 of core PSMKS19 has an error bar (0-460 yr B.P.) that includes the age of the A.D. 1954 Orléansville earthquake and is located near a cable break (Heezen and Ewing, 1955). As no large ( $M>6.5)$ historical events occurred in the area during the 0-460 $\mathrm{yr}$ B.P. time span (Boughacha et al., 2004), T1 likely corresponds to the 1954 earthquake. The lack of events E1 in cores KMDJ07 and KMDJ08, and E2 in core KMDJ07, likely results from the loss of the uppermost deposits in the piston corer. Conversely, the lack of turbidites coeval with T10 in core KMDJ07 cannot be caused by sampling limitations. Because T10 occurs $\sim 500 \mathrm{yr}$ after the previous earthquake, the slope was most likely reloaded with sediments, thus the lack of coeval record in other cores supports that T10 is local and not triggered by a large earthquake.

The strongest argument for interpreting the turbidites as coseismic is their correlation with independent paleoseismic data inland (Sumner et al., 2013), here, the El Asnam fault scarp, the longest fault known in the area. At least eight out of nine paleo-earthquakes are coeval with the submarine record within their error bars (all events except E7; Fig. 3). This clear correlation suggests that ruptures on the El Asnam fault triggered these turbidites. However, other faults in the area may have triggered the turbidites if they ruptured almost synchronously (i.e., within few decades) with the El Asnam paleo-earthquakes. Indeed, although the error bar of event E1 overlaps both the 1954 and 1980 earthquakes, only the first one triggered turbidity flows in the area (Heezen and Ewing, 1955). Sediment prone to failure was probably flushed during the earlier earthquake, thus lowering the probability of a subsequent failure. Similarly, the slight asynchrony of event E7 with an El Asnam paleoearthquake ( $<100 \mathrm{yr})$ may result from bursts of activity on nearby faults. Therefore, it is impossible to assign a turbidite to a specific fault segment, and the number of large earthquakes may exceed the number of turbidites found (i.e., a single turbidite may hide multiple earthquakes). Still, the nine ruptures identified on the El Asnam fault scarp remarkably match the nine widespread turbidites deposited within very short time spans. Turbidites triggered by earthquakes from active faults located in other regions (e.g., the Iberian margin) have no chance to reach our study area, given (1) the large distance $(>250$ $\mathrm{km}$ ) of our coring sites from canyons and major faults of Iberia (Gràcia et al., 2006) and (2) the depth of coring, significantly less than the deepest basin floor (Babonneau et al., 2012).

\section{Earthquake Recurrence and Supercycles}

Although the turbidite record is incomplete for earthquakes occurring closely in time (a few decades), the 13 paleo-events identified define three clusters of seismicity (Fig. 3): C1 (four events in $1800 \pm 250 \mathrm{yr}$ ), C2 (three events in $850 \pm 260 \mathrm{yr}$ ), and C3 (six events in 1650 $\pm 400 \mathrm{yr})$. The distribution is bimodal: the three clusters depict mean recurrence intervals (RIs) of $0.3 \pm 0.2(\mathrm{C} 3), 0.4 \pm 0.2(\mathrm{C} 2)$, and $0.6 \pm 0.4 \mathrm{ka}(\mathrm{C} 1)$ and are separated by two quiescence periods Q1 and Q2 of $1575 \pm 580 \mathrm{yr}$ and $1625 \pm 490 \mathrm{yr}$, respectively (Fig. 3). This distribution suggests 3-4-k.y.-long patterns including clusters of three to six events and periods without major events in between. This variability in earthquake recurrence is akin to the concept of "supercycles" suggested for subduction zones (Goldfinger et al., 2013). Interestingly, similar quiescence periods are found in the southwest Iberian margin (Gràcia et al., 2010) and in central Italy (Benedetti et al., 2013), where slip rates are low. This concept supports alternation of broad phases of strain loading and shorter phases of strain release and implies that fault slip rates are time dependent (Friedrich et al., 2003; Benedetti et al., 2013). Note also that the mean RI in clusters rises progressively $(\mathrm{C} 3,305 \mathrm{yr}$; $\mathrm{C} 2,430 \mathrm{yr}$; $\mathrm{C} 1,580 \mathrm{yr}$; 
Fig. 3), suggesting that strain rates may change through time.

\section{Earthquake Synchrony}

Fault interactions have proved to promote or delay fault activity by stress transfer, sometimes leading to synchronization between fault segments (Scholz, 2010). If slope sediments are prone to failure, turbidites record the activity of any neighboring fault able to cause earthquakes strong enough to trigger turbidity currents (Fig. 4). The cluster-quiescence pattern found here supports the idea that the seismogenic segments (EAFS and other large faults in the area) are in synchrony, at least at the scale of the study region $(\sim 100 \times 100 \mathrm{~km}$; Fig. 1). Knowledge of long-term cycling in the rupture pattern (here, two complete supercycles; Fig. 3) is important because it reveals phases of strain release and loading, therefore a given elapsed time after a clustering period would not necessarily mean a higher hazard. This result thus modifies the probability models of earthquake recurrence (Gomberg et al., 2005) and helps improve seismic hazard assessments.

\section{ACKNOWLEDGMENTS}

We thank GENAVIR for their assistance during the MARADJA and PRISME cruises, and Algerian authorities for permits and logistical supply. IFREMER and the Conseil Général du Finistère funded G. Ratzov's grant. LabexMER (ANR-10-LABX-19-01) and FP7-ENV2013 6.4-3 ASTARTE supported this research. CNRS-INSU Artemis Program provided ${ }^{14} \mathrm{C}$ dates. We thank J.Y. Collot, M.A. Gutscher, and D. Pantosti for fruitful discussions, and L. McNeill, A. Polonia, and four anonymous reviewers for thorough comments.

\section{REFERENCES CITED}

Akkar, S., and Bommer, J.J., 2010, Empirical equations for the prediction of PGA, PGV, and spectral accelerations in Europe, the Mediterranean region, and the Middle East: Seismoogical Research Letters, v. 81, p. 195-206, doi:10.1785/gssrl.81.2.195.

Avouac, J.-P., Meyer, B., and Tapponnier, P., 1992, On the growth of normal faults and the existence of flats and ramps along the El Asnam active fold and thrust system: Tectonics, v. 11, p. 1-11, doi:10.1029/91TC01449.

Babonneau, N., Cattaneo, A., Savoye, B., Barjavel, G., Déverchère, J., and Yelles, K., 2012, The Kramis deep-sea fan off western Algeria: Role of sediment waves in turbiditic levee growth, in Prather, B.E., et al., eds., Application of the Principles of Seismic Geomorphology to ContinentalSlope and Base-of-Slope Systems: Case Studies from Seafloor and Near-Seafloor Analogues: SEPM (Society for Sedimentary Geology) Special Publication 99, p. 293-308.

Barcena, M.A., Cacho, I., Abrantes, F., Sierro, F.J., Grimalt, J.O., and Flores, J.A., 2001, Paleoproductivity variations related to climatic conditions in the Alboran Sea (western Mediterranean) during the last glacial-interglacial transition: The diatom record: Palaeogeography, Palaeoclimatology, Palaeoecology, v. 167, p. 337-357, doi:10.1016/S0031-0182(00)00246-7.

Beldjoudi, H., Delouis, B., Heddar, A., Nouar, O.B., and Yelles Chaouche, A., 2011, The Tadjena earthquake (Mw=5.0) of December 16, 2006 in the Cheliff region (northern Algeria): Waveform modelling, regional stresses, and relation with the Boukadir fault: Pure and Applied Geophysics, v. 169, p. 677-691, doi:10.1007/s00024-011-0337-8.

Benedetti, L., Manighetti, I., Gaudemer, Y., Finkel, R., Malavieille, J., Pou, K., Arnold, M., Aumaître, G., Bourlès, D., and Keddadouche, K., 2013, Earthquake synchrony and clustering on Fucino faults (Central Italy) as revealed from in situ ${ }^{36} \mathrm{Cl}$ exposure dating: Journal of Geophysical Research, v. 118, p. 4948-4974, doi: 10.1002/jgrb.50299.

Boughacha, M.S., Ouyed, M., Ayadi, A., and Benhallou, H., 2004, Seismicity and seismic hazard mapping of northern Algeria: Map of Maximum Calculated Intensities (MCI): Journal of Seismology, v. 8, p. 1-10, doi:10.1023/B:JOSE .0000009513.11031.43.

Cattaneo, A., Babonneau, N., Ratzov, G., Dan, G., Yelles, K., Bracene, R., Mercier de Lepinay, B., Boudiaf, A., and Déverchère, J., 2012, Searching for the seafloor signature of the 21 May 2003 Boumerdes earthquake offshore central Algeria: Natural Hazards and Earth System Sciences, v. 12, p. 2159-2172, doi:10.5194 /nhess-12-2159-2012. 
Einsele, G., Chough, S.K., and Shiki, T., 1996, Depositional events and their records: An introduction: Sedimentary Geology, v. 104, p. 1-9, doi: 10.1016/0037-0738(95)00117-4.

El-Robrini, M., Genesseaux, M., and Mauffret, A., 1985, Consequences of the El Asnam earthquake: Turbidity currents and slumps on the Algerian margin (Western Mediterranean): Geo-Marine Letters, v. 5, p. 171-176, doi:10.1007 /BF02281635.

Friedrich, A., Wernicke, B.P., Niemi, N.A., Bennett, R.A., and Davis, J.L., 2003, Comparison of geodetic and geologic data from the Wasatch region, Utah, and implications for the spectral character of Earth deformation at periods of 10 to 10 million years: Journal of Geophysical Research, v. 108, 2199, doi:10.1029/2001JB000682.

Goldfinger, C., Nelson, C.H., Johnson, J.E., and Party, S.S., 2003, Holocene earthquake records from the Cascadia subduction zone and northern San Andreas Fault based on precise dating of offshore turbidites: Annual Review of Earth and Planetary Sciences, v. 31, p. 555-577, doi: 10.1146/annurev.earth.31.100901.141246.

Goldfinger, C., Ikeda, Y., Yeats, R.S., and Ren, J., 2013, Superquakes and supercycles: Seismological Research Letters, v. 84, p. 24-32, doi: 10.1785/0220110135.

Gomberg, J., Belardinelli, M.E., Cocco, M., and Reasenberg, P., 2005, Time-dependent earthquake probabilities: Journal of Geophysical Research, v. 110, B05S04, doi:10.1029/2004JB003405.

Gràcia, E., et al., 2006, Active faulting offshore SE Spain (Alboran Sea): Implications for earthquake hazard assessment in the Southern Iberian Margin: Earth and Planetary Science Letters, v. 241, p. 734-749, doi:10.1016/j.eps1.2005.11.009.

Gràcia, E., Vizcaino, A., Escutia, C., Asioli, A., Rodés, A., Pallàs, R., Garcia Orellana, J., Lebreiro, S., and Goldfinger, C., 2010, Holocene earthquake record offshore Portugal (SW Iberia): Testing turbidite paleoseismology in a slow-convergence margin: Quaternary Science Reviews, v. 29, p. 1156-1172, doi:10.1016/j.quascirev.2010.01.010.

Heezen, B.C., and Ewing, M., 1955, Orléansville earthquake and turbidity currents: AAPG Bulletin, v. 39 , p. 2505-2514.

Meghraoui, M., Jaegy, R., Lammali, K., and Albarède, F., 1988, Late Holocene earthquake sequences on the El Asnam (Algeria) thrust fault: Earth and Planetary Science Letters, v. 90, p. 187-203, doi:10.1016/0012-821X(88)90100-8.

Pouderoux, H., Proust, J.-N., and Lamarche, G., 2014, Submarine paleoseismology of the northern Hikurangi subduction margin of New Zealand as deduced from turbidite record since $16 \mathrm{ka}$ : Quaternary Science Reviews, v. 84, p. 116- 131, doi:10.1016/j.quascirev.2013.11.015.

Ratzov, G., Collot, J.Y., Sosson, M., and Migeon, S., 2010, Mass transport deposits in the northern Ecuador subduction trench: Result of frontal erosion over multiple seismic cycles: Earth and Planetary Science Letters, v. 296, p. 89-102, doi:10.1016/j.eps1.2010.04.048.

Scholz, C.H., 2010, Large earthquake triggering, clustering, and the synchronization of faults: Bulletin of the Seismological Society of America, v. 100, p. 901-909, doi:10.1785/0120090309.

Stein, R.S., 1999, The role of stress transfer in earthquake occurrence: Nature, v. 402, p. 605-609, doi:10.1038/45144.

Stich, D., Serpelloni, E., de Lis Mancilla, F., and Morales, J., 2006, Kinematics of the IberiaMaghreb plate contact from seismic moment tensors and GPS observations: Tectonophysics, v. 426, p. 295-317, doi:10.1016/j.tecto.2006 .08.004.

Sumner, E.J., Siti, M.I., McNeill, L.C., Talling, P.J., Henstock, T.J., Wynn, R.B., Djajadihardja, Y.S., and Permana, H., 2013, Can turbidites be used to reconstruct a paleoearthquake record for the central Sumatran margin?: Geology, v. 41, p. 763-766, doi:10.1130/G34298.1.

Van Daele, M.E., Cnudde, V., Duyck, P., Pino, M., Urrutia, R., and de Batist, M., 2013, Multidirectional, synchronously triggered seismoturbidites and debrites revealed by X-ray computed tomography (CT): Sedimentology, v. 61, p. 861-880, doi:10.1111/sed.12070.

Manuscript received 12 August 2014 Revised manuscript received 10 January 2015

Manuscript accepted 29 January 2015

GSA Data Repository item 2015120, Figures DR1-DR8 (position map and stratigraphic logs, multiproxy correlations, grain-size analyses, radiocarbon dates, age/depth models, and peak ground acceleration calculations, is available online at www.geosociety .org/pubs/ft2015.htm, or on request from editing@ geosociety.org or Documents Secretary, GSA, P.O. Box 9140, Boulder, CO 80301, USA. 


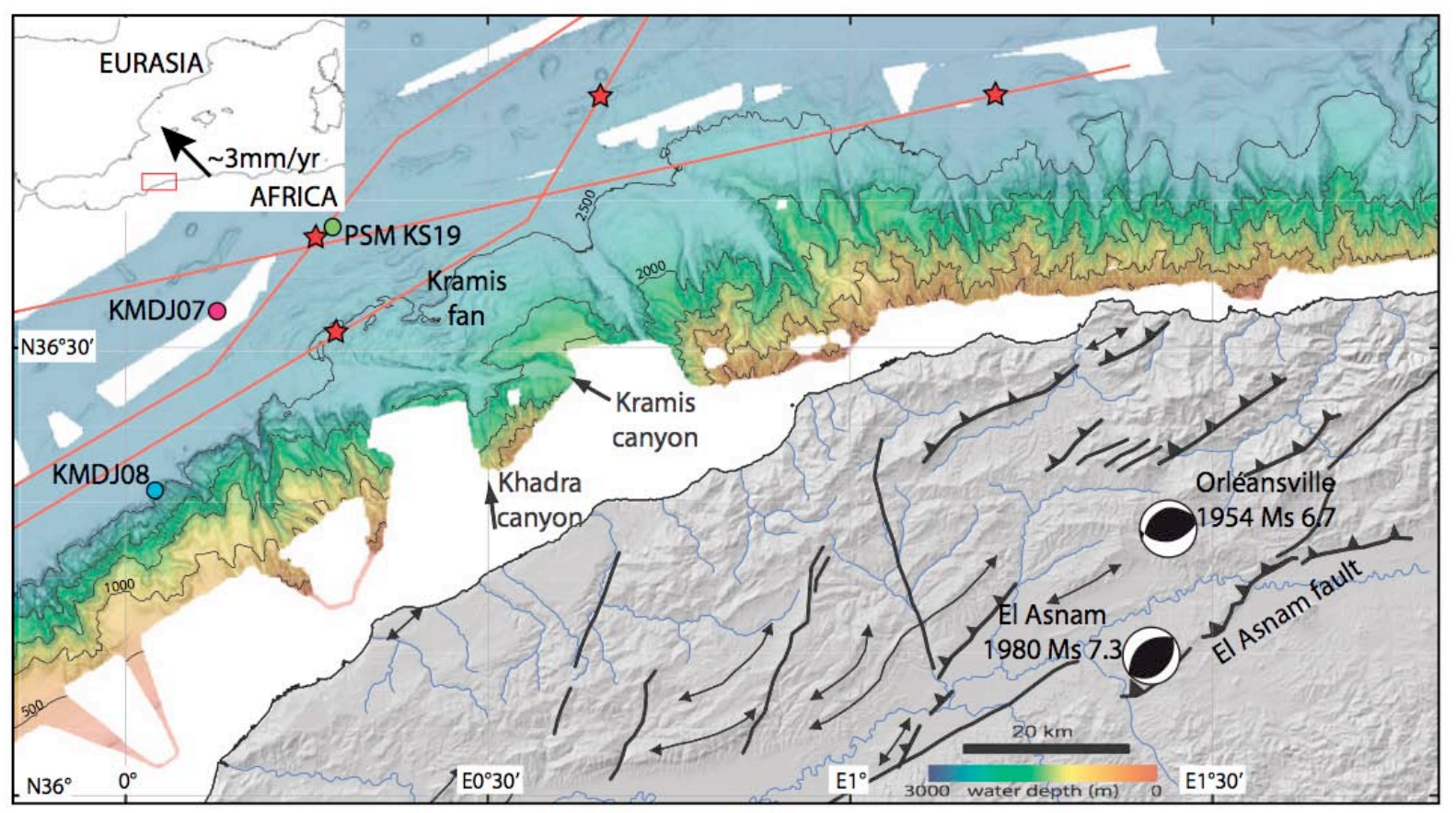

Figure 1. Morphostructural map of northwestern Algerian margin. Inset: Arrow is Africa-Eurasia convergence inferred from GPS (Stich et al., 2006). Map: Black lines on land are the active fault network; double arrows are folds (Beldjoudi et al., 2011). Focal mechanisms of the A.D. 1954 and 1980 earthquakes are from Avouac et al. (1992). Offshore, isobaths interval is $500 \mathrm{~m}$. Red lines are submarine cables, stars are breaks after the 1954 earthquake (after Heezen and Ewing, 1955). Colored circles are sedimentary cores used in this study. 


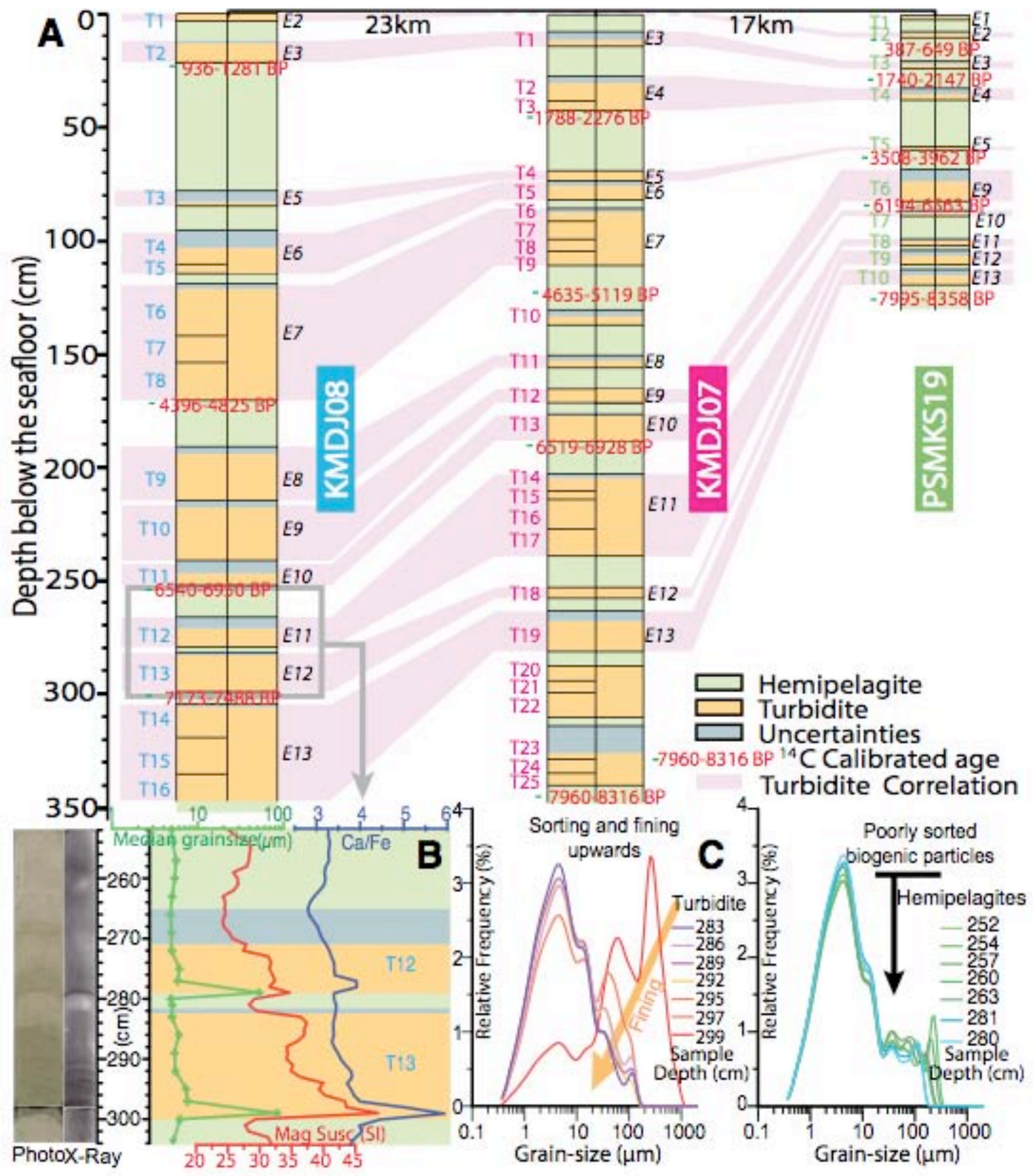

Figure 2. Synthetic logs of cores used for turbidite correlations (A), depicting interpretation from turbidite $(T)$ in each core to widespread events (E1-E13) where turbidites are correlated across numerous cores. Gray layers outline uncertainties on identifying precise turbidite boundaries. Ages (in red) are in years before present. Deposits are discriminated based on photos, X-ray images, magnetic susceptibility (Mag Susc), density, and X-ray fluorescence (B), and on sediment sorting (C). 
El Asnam Fault scarp
Core KMDJ08
Core KMDJ07
Core PSM KS19
Paleo-earthquake
(derived from turbidites)

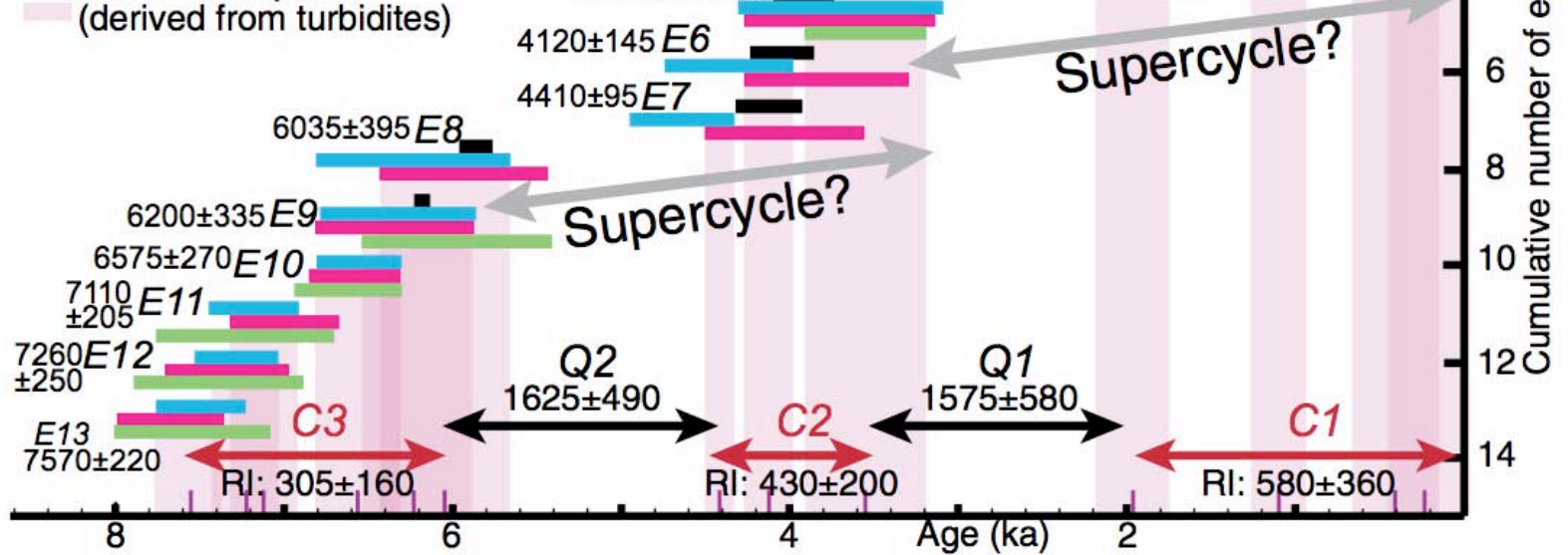

Figure 3. Correlations between ages of events recorded in each core (colored lines) and paleo-earthquake chronology reconstructed across El Asnam fault, Algeria (Meghraoui et al., 1988). Purple bars outline intersection of error bars of turbidite ages, thus probable age of earthquake triggering. Numeric ages for events (E1-E13) are in years before present; recurrence intervals (RI) and time spans for earthquake clusters $(C 1-C 3)$ and quiescence periods $(Q 1-Q 2)$ are in years.

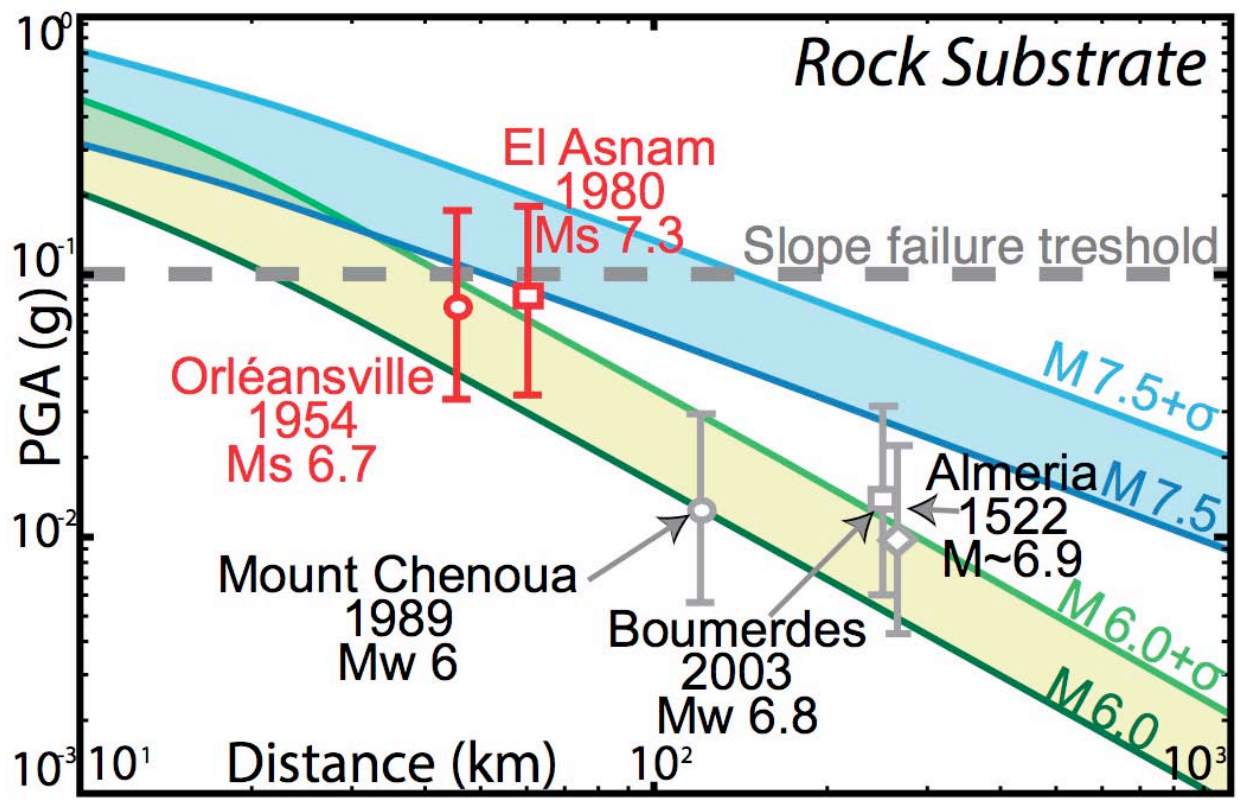

Figure 4. Peak ground acceleration (PGA, $\pm \sigma$ ) predicted for historical earthquakes using Akkar and Boomer (2010) empirical equations for rock sites and strike-slip earthquakes. The $x$ axis corresponds to the closest distance between the fault activated during the earthquake and the area of submarine canyon heads where sediment turbibity currents likely originate. Color stripes outline mean PGA values and mean PGA + $\sigma$ predicted for $M w 6.0$ and $M w 7.5$ earthquakes (see Fig. DR8 [see footnote 1] for further details). The line at PGA $=0.1 \mathrm{~g}$ depicts the limit above which the slope could fail. 
DR1: Detailed bathymetric map of the study area, sites of all the cores initially available for the paleoseismic investigation and synthetic lithologic logs of the cores. On the map, yellow circles show the location of cores, red stars are the locations of cable breaks after the $1954 \mathrm{M}_{\mathrm{S}} 6.7$ Orléansville earthquake. On the lithologic logs, the red rectangles show the core sections used in the study. Sedimentological analyses are detailed in SM2.

The coring strategy was established in order to (1) collect turbidites originated from independent sedimentary system to test synchroneity and infer a regional trigger of turbidites, (2) obtain a record with amounts of datable hemipelagic deposits between turbidites, (3) avoid climatically triggered turbidites, and (4) collect turbidites associated at least to the 1954 Earthquake, thus located close to the cable breaks,

This figure shows encountered issues while establishing a coring strategy for a turbidite paleoseismology investigation:

A) No datable hemipelagic deposits: For example, cores KMDJ24 and KMDJ22 did not contain any intervening hemipelagites between turbidites thus discarding dating possibilities. Indeed, these two cores are most probably too axially located compared to the sediment transport axis. Turbidity currents at these sites are too energetic, thus eroding any intervening deposits. Moreover, these two cores are also likely too proximally located, contain much more turbidites than the distal cores, and probably record flood- or storm-triggered turbidites. More generally, all the cores contain a greater amount of turbidites without intervening hemipelagites during the Last Glacial Maximum and the sea-level rise, and probably record climatic events. We therefore discarded cores KMDJ22, KMDJ24, and the periods before $~ 8 \mathrm{ka}$ on all the other cores.

B) Incomplete turbidite record: Core KMDJ23 was collected on a levee of the channel in order to avoid basal erosion by turbidity currents and climatically-driven turbidites. Unfortunately, turbidites in this core are scarce, very fine grained and difficult to identify. The core most likely contains an incomplete turbidite record and was discarded for detailed investigation.

C) Missing core tops: Loss of the uppermost deposits may occur with a piston corer as exemplified by cores KMDJ06 and PSMKS20. Although located in independent sedimentary systems and showing a good alternation of turbidites and hemipelagites, ${ }^{14} \mathrm{C}$ datings near the top of the cores show that $\sim 6 \mathrm{kyr}$ and $\sim 10 \mathrm{kyr}$ are missing respectively. We therefore discarded these two cores. 

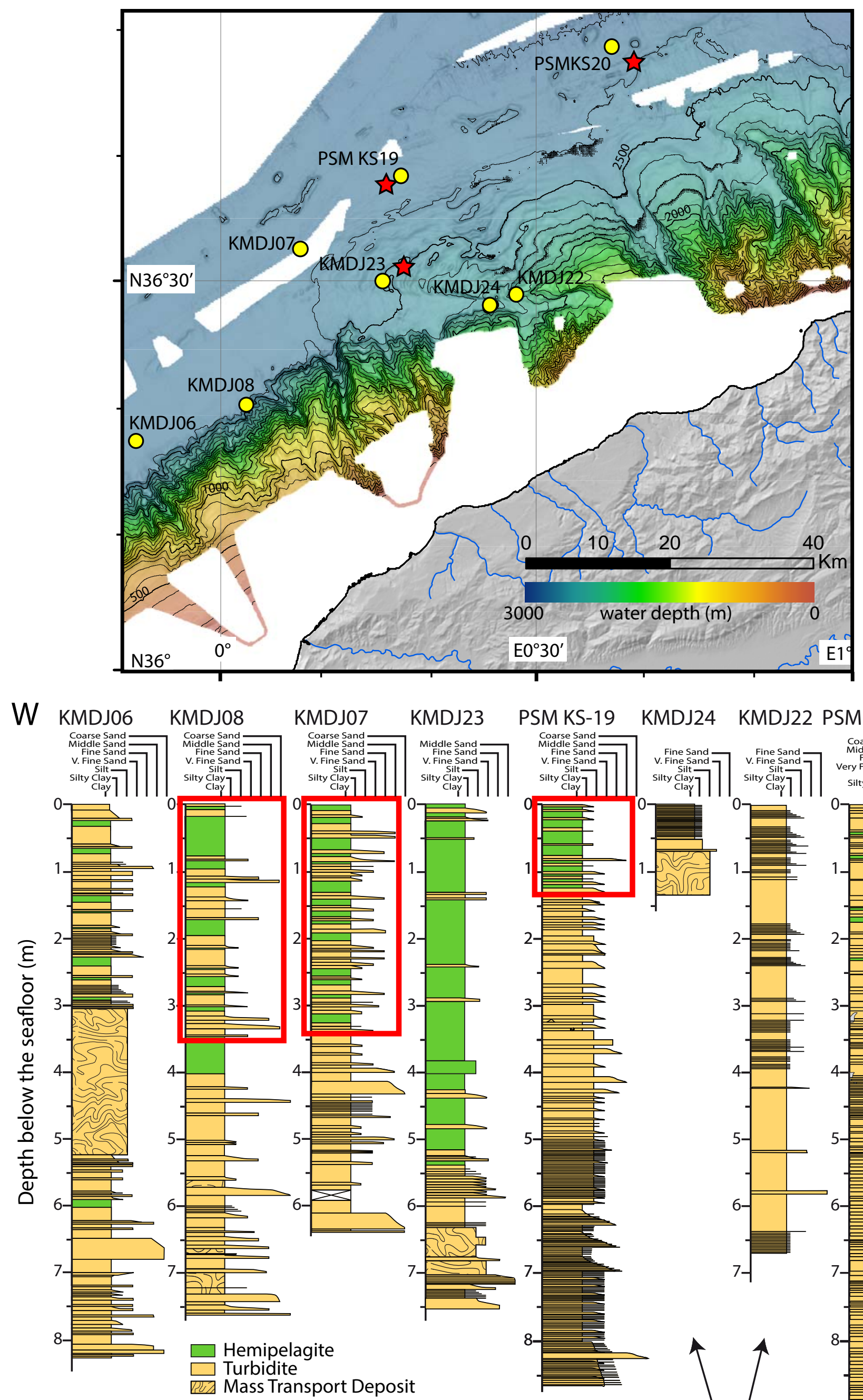

$\begin{array}{ccc}\begin{array}{c}\text { Missing top } \\ (\sim 6 \mathrm{kyr})\end{array} \quad \text { OK } & \text { OK } & \begin{array}{c}\text { Core sheltered } \\ \text { from turbidites } \\ \text { Incomplete record }\end{array}\end{array}$

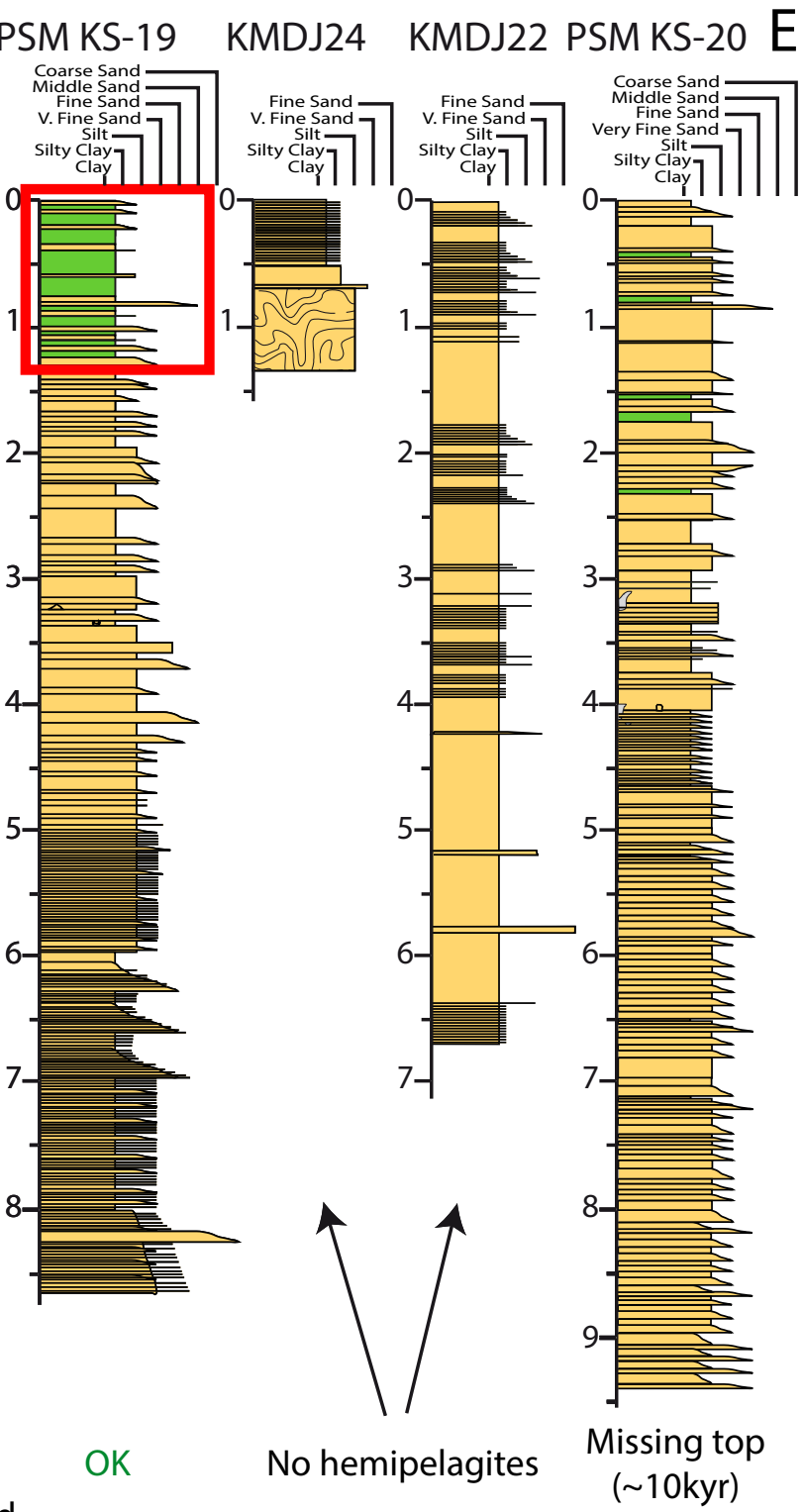


DR2: Detailed view of cores KMDJ08, KMDJ07, and PSMKS19. Turbidites and hemipelagites were discriminated based on visual description, X-Ray photography, Magnetic Susceptibility, Gamma Density, $\mathrm{Ca} / \mathrm{Fe}$ ratios, and granulometry.

X Ray photography was performed using the SCOPIX system at the University of Bordeaux I (Migeon et al., 1999); Magnetic Susceptibility was performed using a hand operating, high resolution, BARTINGTON surface sensor with 10s acquisitions; Gamma Density was performed on unopened cores with a GEOTEK Multi Sensor Core Logger; Semi-quantitative major elements composition was performed using a X-Ray Fluorescence Core Scanner. All these analyses were acquired at a step of $1 \mathrm{~cm}$. Finally, granulometry was acquired using a COULTER LS230 Laser Granulometer, at a step ranging between one and five centimeters depending on the homogeneity of deposits.

We outlined the portions where uncertainties on the discrimination of deposits remain, such as within bioturbated sediment.

The correlation from site to site was based on the age of each turbidite or stack of turbidites. Please refer to SM3 to SM6 for details on ${ }^{14} \mathrm{C}$ datings and establishment of age models. 

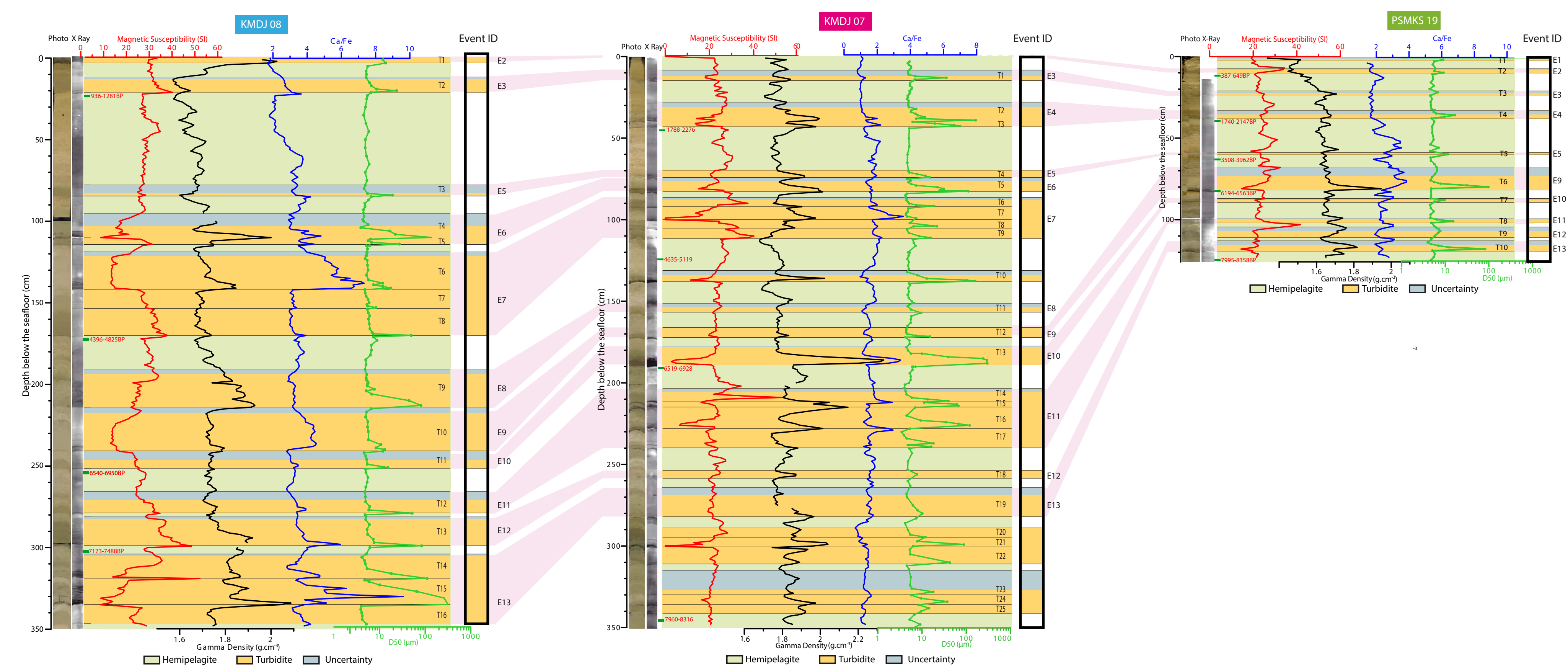
DR3: Detailled grain-size histograms of all the analyses performed on cores KMDJ08, KMDJ07, and PSMKS19. Analyses were performed at 1 to $5 \mathrm{~cm}$ intervals depending on the variation of sedimentary facies. Each sample was collected with a $0.5 \mathrm{~cm}$-large spatula, and analysed with a COULTER LS230 Laser Diffraction Particle Size Analyser. Facies and grain-size were interpreted using multiple proxies: visual identification, Xray radioscopy, gamma density, magnetic susceptibility, and XRF (SM2).

These analyses aim to accurately point the boundaries between hemieplagites and turbidites (see main text for details). As the difference between turbidite tails and hemipelagites may not be obvious, we systematically performed a serie of measurement from base to top of turbidite to infer the subtle evolution of grainsize during fining upwards, and pointed out where the grainsize signature changed. The hemipelagic deposit aver usually less sorted in these cores, characterized by a plateau in grainsize for $\sim 30-300 \mu \mathrm{m}$ (see main text). However, hemipelagites properties may vary, and where sorting was less obvious, the interpretation was helped by the other proxies. We considered unclear intervals as uncertainties. 
KMDJ08

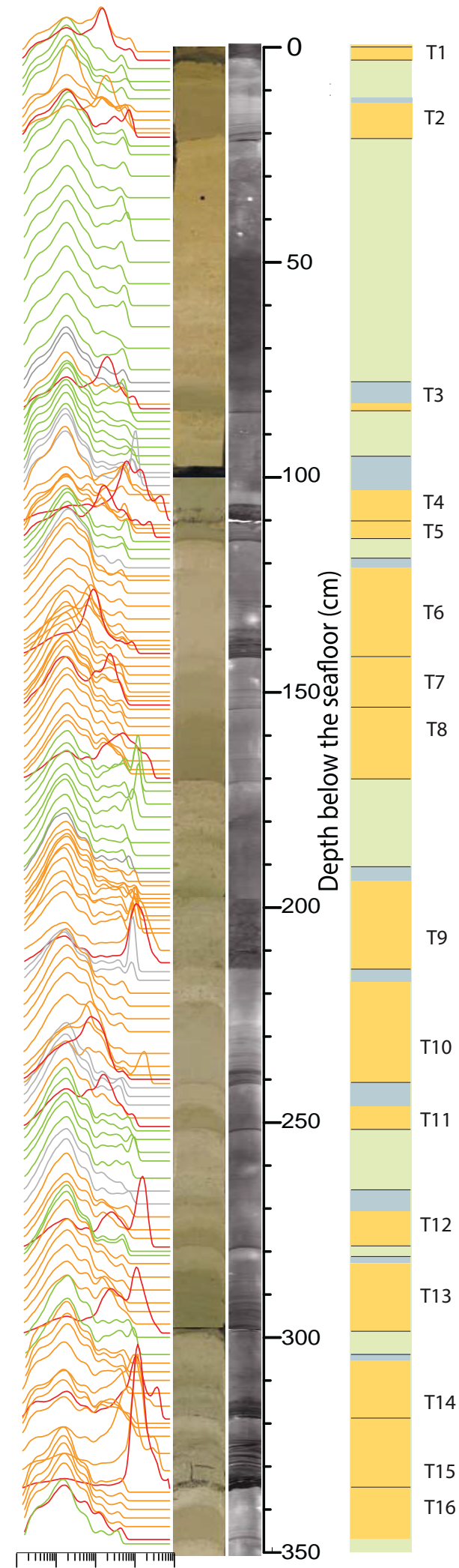

$\begin{array}{cccc}0.1 & 10 & 1001000 \\ \text { Grain-size }(\mu \mathrm{m}) & 0\end{array}$

9

10

11

12

13

14

T15

T16
KMDJ07
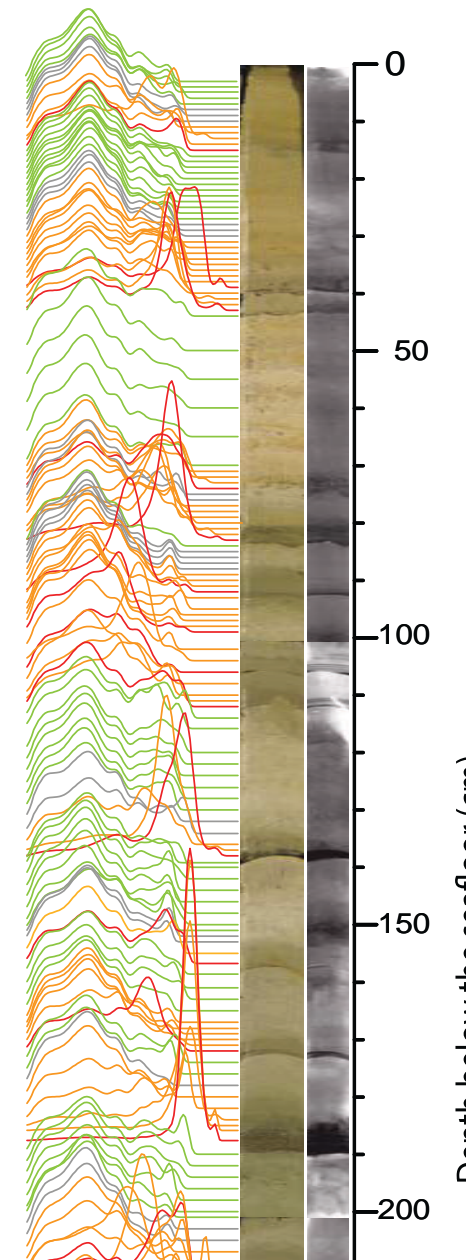

Turbidite ID

Photo X Ray

PSMKS19

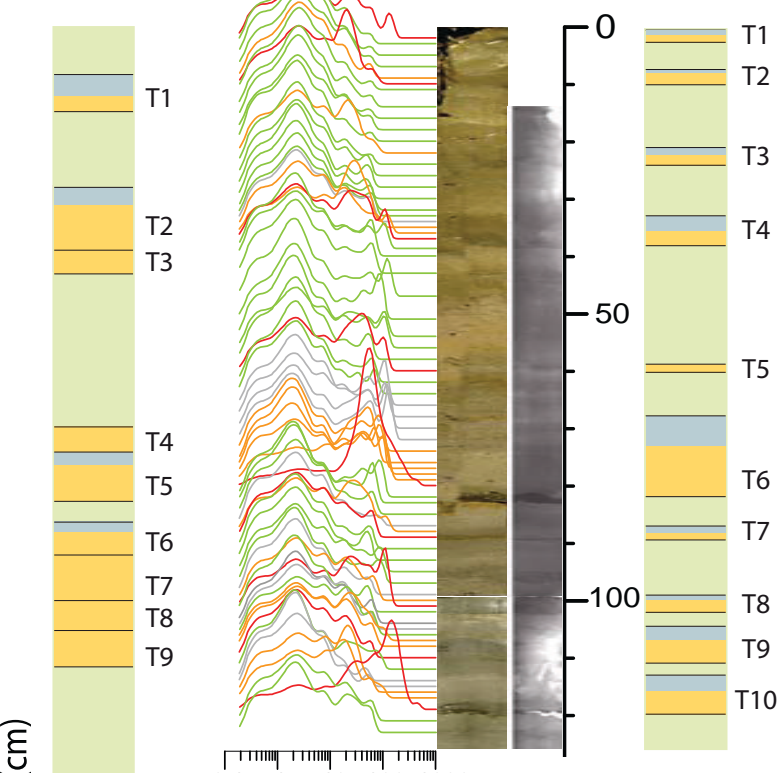

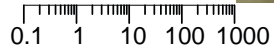

Grain-size $(\mu \mathrm{m}) \quad$ Turbidite ID Photo X Ray

Facies interpretation

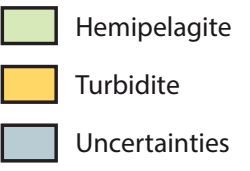

Grain-size analyses

_- Hemipelagite

__ Turbidite

_ Base of turbidite

__ Uncertainies

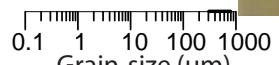
Grain-size $(\mu \mathrm{m})$
Photo X Ray


DR4: Radiocarbon dates used to construct the age model. We performed radiocarbon dating using 13 samples of 1 to $2 \mathrm{~cm}$-thick slices of hemipelagic sediment. We handpicked $>10 \mathrm{mg}$ of $>150 \mu \mathrm{m}$-diameter foraminifers per date. We preferentially used species Globigerinoides Ruber and Globigerinoides Sacculifer because they are common species living in shallow waters $(0-50 \mathrm{~m})$, and completed with Globigerinoides Bulloides $(0-200 \mathrm{~m})$ or mixed planktonic foraminifers to reach $10 \mathrm{mg}$ when needed. ${ }^{14} \mathrm{C}$ AMS dating were then processed at the CAIS Lab (University of Georgia - Sample codes UGAMS) or at the French national facility ARTEMIS (sample codes SacA). To obtain accurate dating, we calibrated the radiocarbon ages with the OxCal software (Ramsey, 2008) using the Marine09 curve. In the Western Mediterranean sea offshore Algeria, as marine radiocarbon reservoir may vary a lot (Reimer and McCormac, 2002), we used a standard $\Delta \mathrm{R}=0$ value, and an extreme $\Delta \mathrm{R}=161 \pm 40 \mathrm{yr}$ measured offshore Algeria (Reimer and McCormac, 2002), then considered the whole age interval as an uncertainty bar $\Delta \mathrm{R}=101 \pm 100 \mathrm{yr}$. 
DR5-DR7: Age / Depth models used to calculate the age of each turbidite / event in cores KMDJ08, KMDJ07, and PSMKS19.

Because each turbidite is located few to tens centimeters away from dated hemipelagic samples, it is necessary to interpolate / extrapolate the time span of each intervening hemipelagic interval. We used a Bayesian model of deposition P_sequence implemented in the OxCal software (Ramsey, 2008). The program considers hemipelagic sedimentation as a random process, and takes into account variation in the sedimentation rates. Thus, uncertainties increase with distance from calibrated age samples. The $k$ value determines the regularity of sedimentation rates: a high value ( 1 or more) considers an almost homogeneous deposition. Erosion is observed at the base of numerous turbidites, and we cannot quantify it. We therefore intentionally chose a low value of $k(0.1)$ in order to reflect high variability of sedimentation rates and account for basal erosion.

For each core, we computed two age/depth models: (A) considering minimum turbidite thickness were uncertainties on the boundary between hemipelagites existed, and (B) considering maximum turbidite thickness. As the modeled turbidite age distribution could differ between the two models we considered the sum of the distributions as an error bar for each turbidite (C). The bars below each age distribution corresponds to 2 sigma. 


\begin{tabular}{|c|c|c|c|c|c|c|c|c|c|}
\hline Core & $\begin{array}{c}\text { Lat } \\
\left(\operatorname{dec}^{\circ}\right) \\
\end{array}$ & $\begin{array}{c}\text { Lon } \\
\left(\operatorname{dec}^{\circ}\right)\end{array}$ & $\begin{array}{c}\text { Water } \\
\text { depth } \\
(\mathrm{m})\end{array}$ & $\begin{array}{c}\text { Core } \\
\text { length } \\
(\mathrm{m})\end{array}$ & $\begin{array}{l}\text { AMS Lab } \\
\text { reference }\end{array}$ & $\begin{array}{c}\text { Depth in } \\
\text { the core } \\
(\mathrm{cm})\end{array}$ & Foraminifer species & $\begin{array}{l}\text { Radiocarbon } \\
\text { age }(\mathrm{yr} \pm 1 \sigma)\end{array}$ & 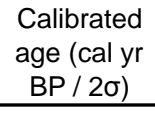 \\
\hline KMDJ08 & 36.3362 & 0.0462 & 2631 & 7.65 & $\begin{array}{l}\text { UGAMS } 9291 \\
\text { UGAMS } 9292 \\
\text { UGAMS } 9293 \\
\text { UGAMS } 9294\end{array}$ & $\begin{array}{c}23 \\
171 \\
253 \\
303\end{array}$ & $\begin{array}{l}\text { G. ruber, G. sacculifer, G. bulloides } \\
\text { G. ruber, G. sacculifer, G. bulloides } \\
\text { G. ruber, G. sacculifer, G. bulloides } \\
\text { G. ruber, G. sacculifer, G. bulloides }\end{array}$ & $\begin{array}{l}1660 \pm 25 \\
4540 \pm 25 \\
6390 \pm 25 \\
6910 \pm 25\end{array}$ & $\begin{array}{c}936-1281 \\
4396-4825 \\
6540-6950 \\
7173-7488 \\
\end{array}$ \\
\hline KMDJ07 & 36.5403 & 0.1267 & 2630 & 6.68 & $\begin{array}{l}\text { UGAMS } 8785 \\
\text { SaCA } 29350 \\
\text { UGAMS } 8786 \\
\text { UGAMS } 8788\end{array}$ & $\begin{array}{c}45 \\
124-125 \\
\\
190 \\
345\end{array}$ & $\begin{array}{l}\text { G. ruber, G. sacculifer, G. bulloides } \\
\text { G. ruber, G. sacculifer } \\
\text { Mixed Planctonic Foraminifers } \\
\text { Mixed Planctonic Foraminifers }\end{array}$ & $\begin{array}{l}2590 \pm 25 \\
4745 \pm 30 \\
6370 \pm 25 \\
7770 \pm 25\end{array}$ & $\begin{array}{l}1788-2276 \\
4635-5119 \\
\\
6516-6928 \\
7960-8316\end{array}$ \\
\hline $\begin{array}{l}\text { PSM } \\
\text { KS19 }\end{array}$ & 36.6340 & 0.2863 & 2626 & 8.65 & $\begin{array}{l}\text { UGAMS } 8782 \\
\text { UGAMS } 8783 \\
\text { SacA } 29351 \\
\text { SacA } 21669 \\
\text { UGAMS } 8784\end{array}$ & $\begin{array}{c}11 \\
39 \\
63-64 \\
82 \\
127\end{array}$ & $\begin{array}{l}\text { G. ruber, G. sacculifer, G. bulloides } \\
\text { G. ruber, G. sacculifer, G. bulloides } \\
\text { G. ruber, G. sacculifer } \\
\text { G. ruber, G. sacculifer } \\
\text { Mixed Planctonic Foraminifers }\end{array}$ & $\begin{array}{l}1020 \pm 25 \\
2430 \pm 25 \\
3885 \pm 30 \\
6045 \pm 30 \\
7820 \pm 25\end{array}$ & $\begin{array}{c}387-649 \\
1740-2147 \\
3508-3962 \\
6194-6563 \\
7995-8358\end{array}$ \\
\hline
\end{tabular}




\section{KMDJ 08}
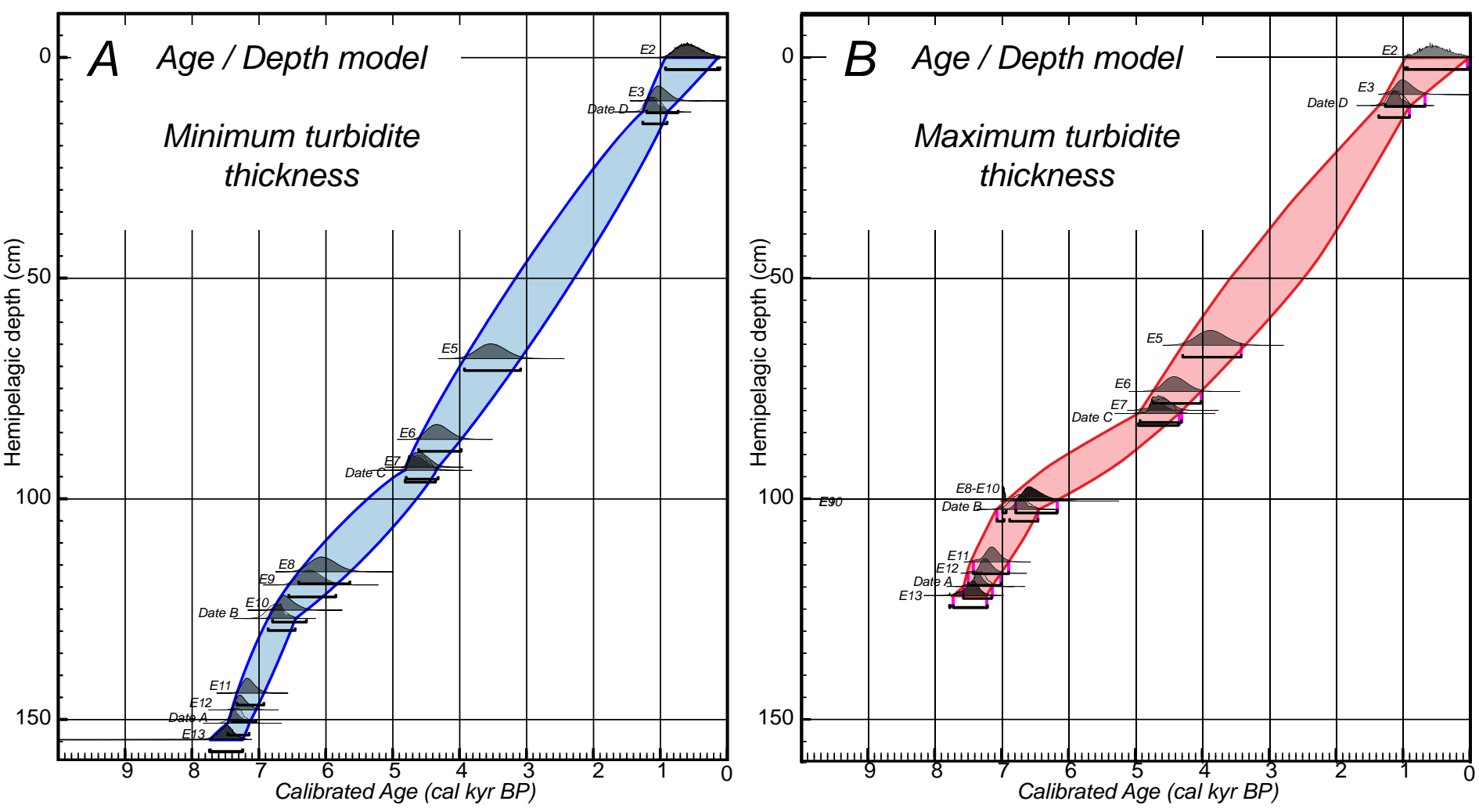

C Total age probability
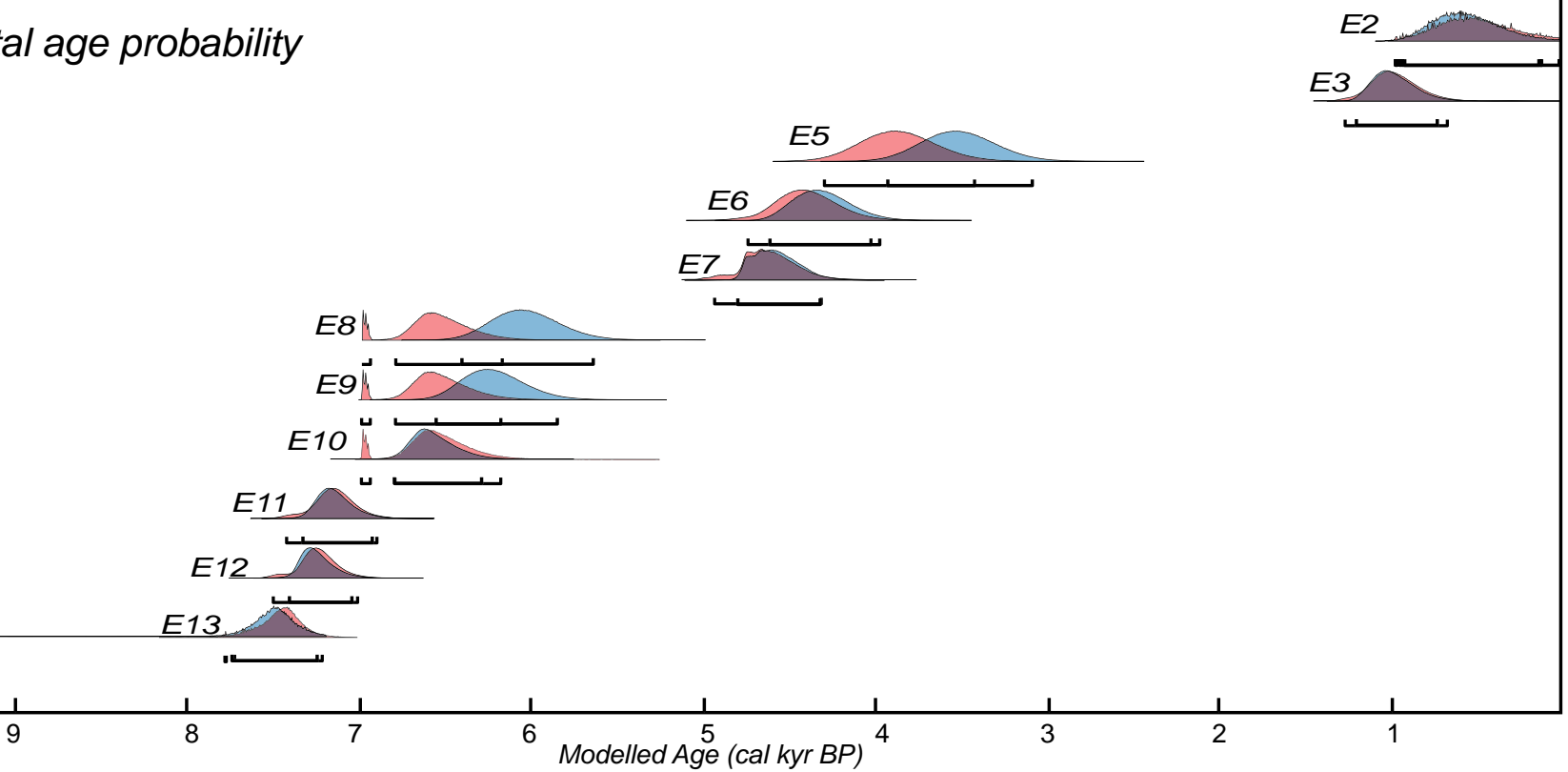


\section{KMDJ 07}
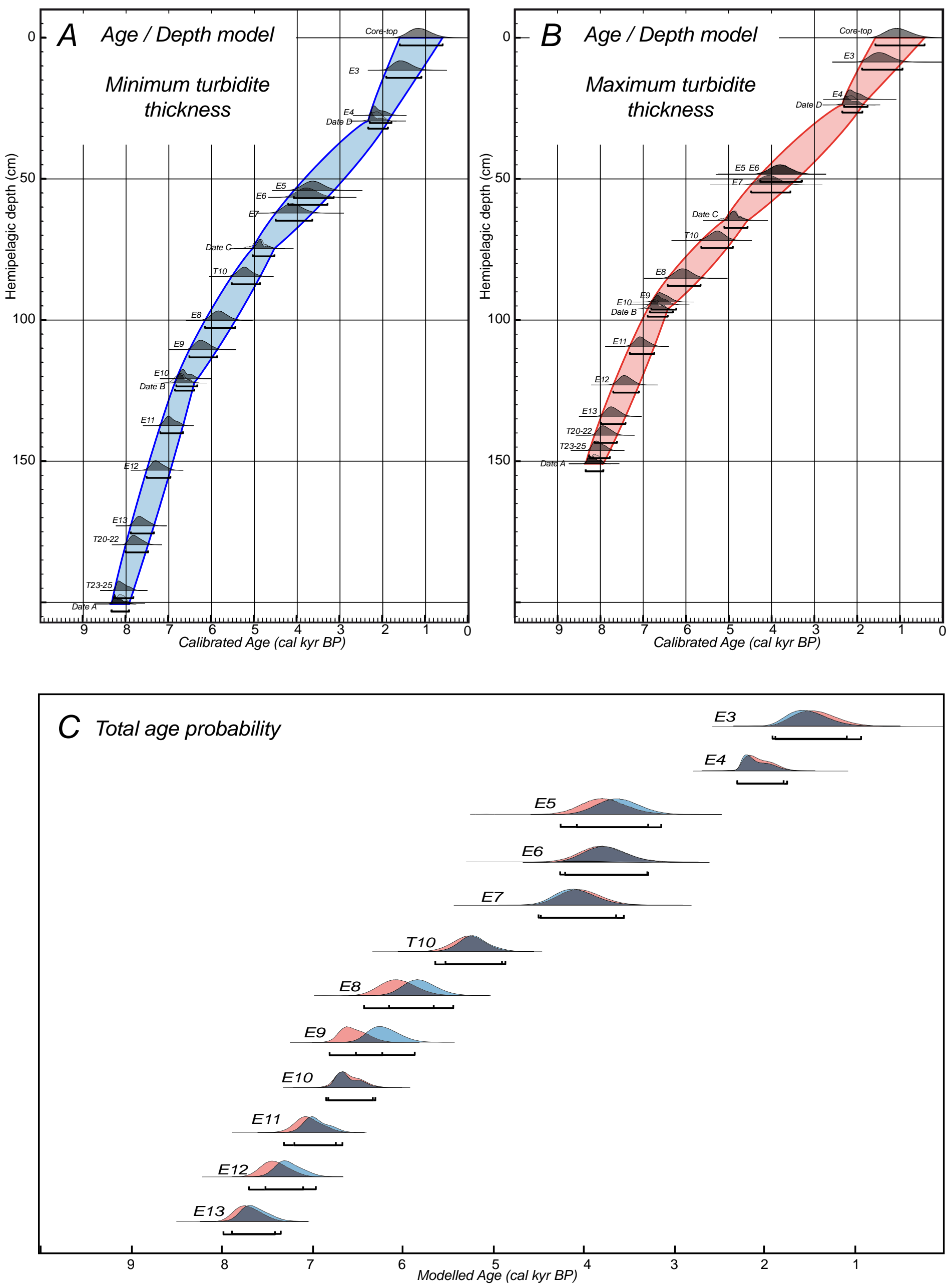

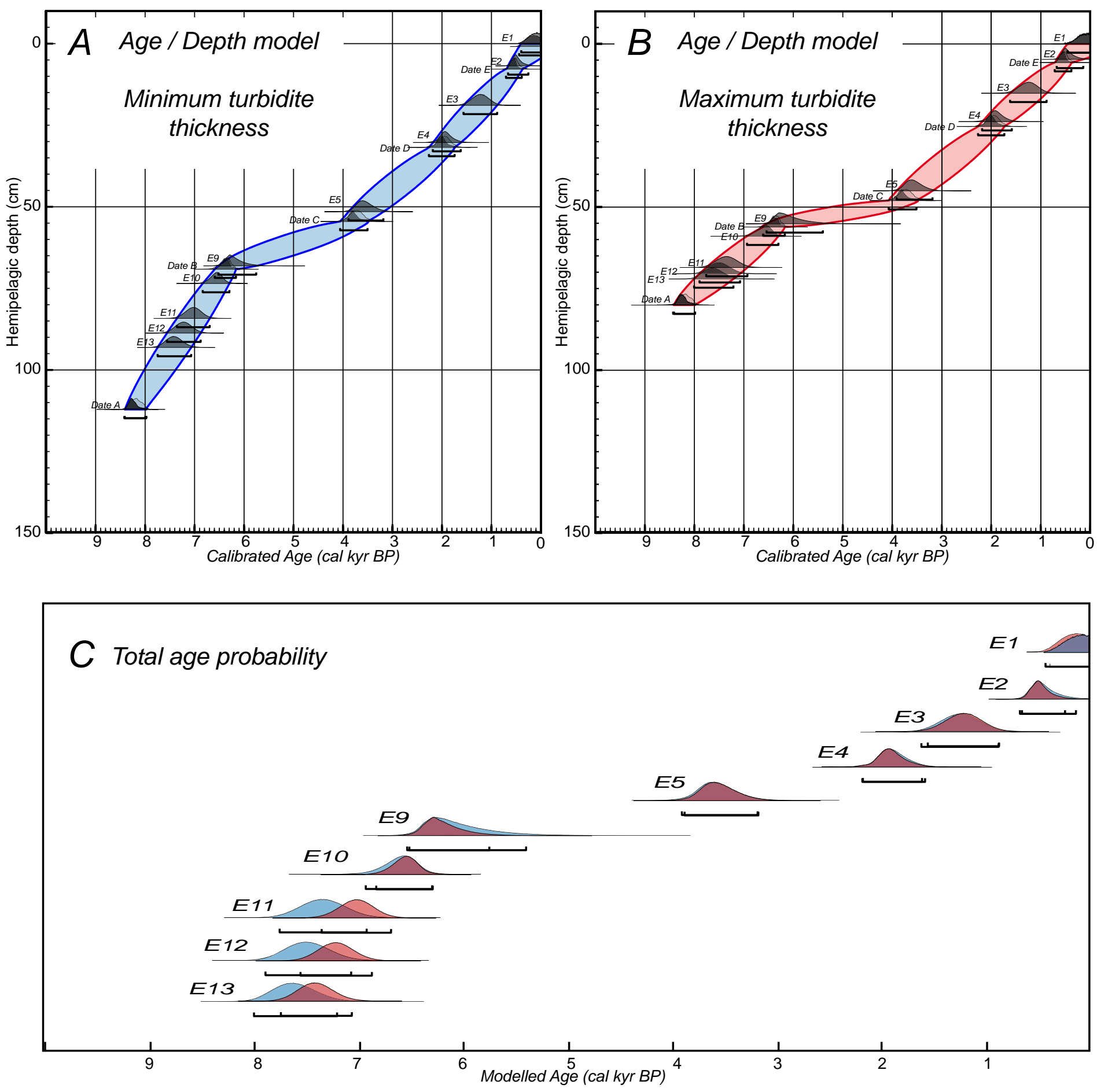
DR8: Peak ground acceleration $(P G A \pm \sigma)$ predicted for historical earthquakes using Akkar and Bommer (2010) empirical equations for rock sites and strike-slip earthquakes. The $\mathrm{x}$ axe corresponds to the closest distance between the fault activated during the earthquake and the area of submarine canyon heads where sediment turbibity currents likely originate. Color stripes outline mean PGA values and mean PGA+ $\sigma$ predicted for Mw 6.0 and Mw 7.5 earthquakes (Fig. DR8 for further details). The line at $P G A=0.1 \mathrm{~g}$ depicts the limit above which the slope could fail. Historical earthquakes include: 1522 M 6.9 Almeria (Martinez-Solares and Mezcua, 2002), 1954 Ms6.7 Orléansville (McKenzie, 1972), 1980 Ms7.3 El Asnam (Deschamps et al., 1982), 1989 Mw6.0 Mont Chenoua (Bounif et al, 2003), and 2003 Mw6.8 Boumerdes (Bounif et al., 2004)

According to geotechnical analyses performed on the sediment cover of the Algerian continental slope, slope failures should occur at PGA values larger than 0.1g/0.2g (Dan et al., 2009). Given the distance of the site from the faults, historically, only the 1954 Ms6.7 Orléansville and $1980 \mathrm{Ms7.3}$ El Asnam, were able to trigger slope failure. However, cable break record proves that only the first did, supporting that the slope was flushed and not enough sediment prone to failure was deposited between the two earthquakes. The 2003 Mw6.8 Boumerdes and 1522 M 6.9 Almeria earthquakes, although of large magnitude are located too far from the studied area, whereas the 1989 Mw6.0 Mont Chenoua earthquake, although coastal had a too low magnitude.

\section{References}

Akkar, S., and Bommer, J.J., 2010, Empirical Equations for the Prediction of PGA, PGV, and Spectral Accelerations in Europe, the Mediterranean Region, and the Middle East: Seismological Research Letters, v. 81, p. 195-206.

Bounif, A., Bezzeghoud, M., Dorbath, L., Legrand, D., Deschamps, A., Rivera, L., and Benhallou, H., 2003, Seismic source study of the 1989, October 29, Chenoua (Algeria) earthquake from aftershocks, broad-band and strong ground motion records: Annals of Geophysics, v. 46, p. 625-646.

Bounif, A., Dorbath, C., Ayadi, A., Meghraoui, M., Beldjoudi, H., Laouami, N., Frogneux, M., Slimani, A., Alasset, P., Kherroubi, A., Ousadou, F., Chikh, M., Harbi, A., Larbes, S., and Maouche, S., 2004, The 21 May 2003 Zemmouri (Algeria) earthquake Mw 6.8: Relocation and aftershock sequence analysis: Geophys. Res. Lett., v. 31.

Dan, G., Sultan, N., Savoie, B., Deverchere, J., and Yelles, K., 2009, Quantifying the role of sandy-silty sediments in generating slope failures during seismic shaking: Example from the Algerian margin: International Journal of Earth Sciences, v. 98, p. 769-789.

Deschamps, A., Gaudemer, Y., and Cisternas, A., 1982, The El Asnam, Algeria, earthquake of 10 October 1980: Multiplesource mechanism determined from longperiod records: Bulletin of the Seismological Society of America, v. 72, p. 1111-1128

Martinez-Solares, J.M., and Mézcua, J., 2002, Catálogo Sísmico de la Península Ibérica (880 B.C.-1900 A.D.): Madrid, Monografía No. 18, Instituto Geográfico Nacional, 253 p.

McKenzie, D.P., 1972, Active tectonics of the Mediterranean region: Geophys. J. R. Astron.Soc, v. 30, p. 109185

Migeon, S., Weber, O., Faugeres, J.C., and Saint-Paul, J., 1999, SCOPIX: a new X-ray imaging system for core analysis: Geo-Marine Letters, v. 18, p. 251-255

Ramsey, C.B., 2008, Deposition models for chronological records: Quaternary Science Reviews, v. 27 , p. 4260.

Reimer, P.J., and McCormac, F.G., 2002, Marine radiocarbon reservoir corrections for the Mediterranean and Aegean Seas: Radiocarbon, v. 44, p. 159-166. 


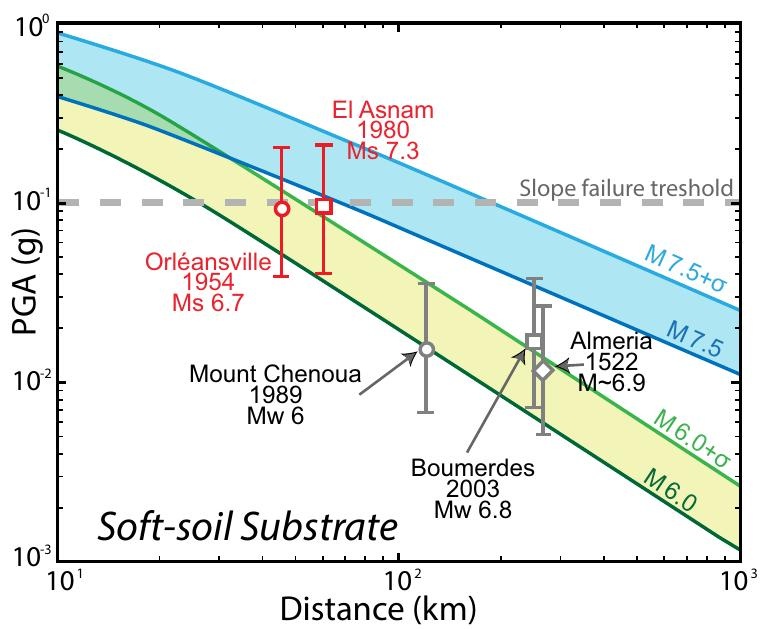

